\title{
Transcriptional Modulation of the ERK1/2 MAPK and NF-kB Pathways in Human Urothelial Cells After Trivalent Arsenical Exposure: Implications for Urinary Bladder Cancer
}

\author{
Kathryn A. Bailey ${ }^{1}$, Kathleen Wallace ${ }^{2}$, Lisa Smeester ${ }^{1}$, Sheau-Fung Thai $^{2}$, \\ Douglas C. Wolf ${ }^{2}$, Stephen W. Edwards ${ }^{2}$ and Rebecca C. Fry ${ }^{1, *}$
}

${ }^{1}$ Department of Environmental Sciences and Engineering, UNC Gillings School of Global Public Health, University of North Carolina at Chapel Hill, NC 27599, USA

${ }^{2}$ National Health and Environmental Effects Research Laboratory, Office of Research and Development, U.S. Environmental Protection Agency, Research Triangle Park, NC 27711, USA

\begin{abstract}
Chronic exposure to drinking water contaminated with inorganic arsenic (iAs) is associated with an increased risk of urinary bladder (UB) cancers in humans. The exact role of specific iAs metabolite(s) in As-mediated carcinogenesis remains largely unknown. Experimental evidence suggests that trivalent arsenicals, namely arsenite $\left(\mathrm{iAs}^{\mathrm{III}}\right)$ and two of its metabolites, monomethylarsonous acid (MMA ${ }^{\text {III})}$ and dimethylarsinous acid (DMA ${ }^{\text {III }}$ ), are possible proximate UB carcinogens. Here, we used a transcriptomics approach to examine perturbed molecular pathways in a human urothelial cell line (UROtsa) after short-term exposure to iAs ${ }^{\prime \prime \prime}, M_{M A}{ }^{\prime \prime \prime}$ and DMA ${ }^{\prime \prime \prime}$. Molecular pathways containing genes that encode proteins implicated in UB cancer development were perturbed by both MMA"I and DMA ${ }^{\prime \prime \prime}$. These pathways included those of the extracellular signal-regulated kinase 1/2 mitogen-activated protein kinase (ERK 1/2 MAPK) and nuclear factor kappa beta (NF-кB). Together, these results may inform the current understanding of effects in the UB induced by acute As exposure and the relationship of these effects with As-mediated carcinogenesis.
\end{abstract}

Keywords: Arsenite, gene expression, microarray, urinary bladder cancer, extracellular signal-regulated kinase 1/2 mitogen-activated protein kinase, nuclear factor kappa beta, inflammation, monomethylarsonous acid, dimethylarsinous acid, UROtsa, MMA"', DMA ${ }^{\prime \prime \prime}$.

\section{INTRODUCTION}

Chronic arsenic (As) exposure is associated with the development of cardiovascular disease, diabetes and various cancers [1]. The most common source of chronic As exposure worldwide is drinking water contaminated with inorganic forms of As (iAs) from natural, geologic sources [2, 3]. Inorganic As exists in drinking water as a mixture of two oxidation states, namely trivalent arsenite (iAs ${ }^{\text {III }}$ ) and pentavalent arsenate $\left(\mathrm{iAs}^{\mathrm{V}}\right)$, which predominate in anaerobic and aerobic conditions, respectively [4]. Millions of people worldwide and an estimated tens of millions in Bangladesh alone are exposed to iAs levels in drinking water that far exceed the World Health Organization's recommended limit of $10 \mathrm{ppb}$ [5-7].

Although iAs is classified as a known human carcinogen with primary targets of the skin, lung, and urinary bladder (UB) [8], the mode of action (MOA) of iAs carcinogenesis remains largely undefined [9-11]. Experimental evidence supports the generation of oxidative stress as a major factor, which can contribute to carcinogenesis by causing macromolecule (e.g.

*Address corresponding to this author: 135 Dauer Drive, Campus Box 7431, Chapel Hill, NC, 27599, USA; Tel: 919-843-6864; Fax: 919-966-7991; E-mail: rfry@unc.edu
DNA) damage and stimulating signaling pathways that control processes such as proliferation, differentiation and apoptosis [11-14]. Arsenic can exert other potentially carcinogenic effects on cells that are not necessarily associated with oxidative stress. For instance, while they are not point mutagens, arsenicals can induce other genetic alterations such as chromosomal aberrations [15, 16], can bind and inhibit enzymes [17], and can influence gene expression by altering the epigenome [18].

Determining which of these effects is a key event in As carcinogenesis is complicated by iAs ${ }^{I I / N}$ metabolism. Arsenite and arsenate are biotransformed in humans and rodents to yield several trivalent and pentavalent methylated arsenical metabolites. During this process, individual methyl groups are added to iAs in a stepwise, unidirectional manner [19]. Chronic exposure to $\mathrm{iAs} \mathrm{s}^{\mathrm{III} / \mathrm{V}}$ results in six major arsenicals in human urine in which $10-30 \%$ of the total As content exists as trivalent and pentavalent $\mathrm{iAs}\left(\mathrm{iAs}{ }^{\mathrm{III}+\mathrm{V}}\right.$ ), and $10-30 \%$ exists as the monomethylated forms monomethyl-

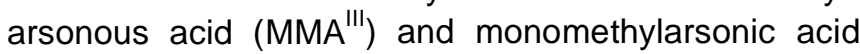
$\left(\mathrm{MMA}^{\mathrm{V}}\right)$. The remaining $60-80 \%$ exists as the trivalent/ pentavalent dimethylated species dimethylarsinous acid (DMA ${ }^{\mathrm{III}}$ ) and dimethylarsinic acid $\left(\mathrm{DMA}^{\mathrm{V}}\right)$ [20-22]. One or more of these methylated arsenicals may 
contribute to the carcinogenic effect of chronic iAs exposure [23]. Not all methylated arsenicals have equivalent biological effects. For example, in general the trivalent arsenicals $\mathrm{MMA}^{\mathrm{III}}$ and $\mathrm{DMA}^{\mathrm{III}}$ are more cytotoxic in vitro than their pentavalent counterparts and $\mathrm{iAs} \mathrm{s}^{\mathrm{III} / \mathrm{V}}$ [24] and have been considered likely carcinogenic arsenicals in vivo [25].

Recently, we examined the gene expression profiles of normal human epidermal keratinocytes (NHEKs) after short-term exposure $(24 \mathrm{~h})$ to $\mathrm{iAs}^{\mathrm{III}}, \mathrm{MMA}^{\mathrm{III}}$ and $D A^{\prime \prime \prime}$ [26]. Several trends in gene expression were observed after exposure to iAs" ${ }^{\prime \prime \prime}$ and especially MMA ${ }^{\prime \prime \prime}$ that were consistent with several proposed mechanisms of As-mediated skin carcinogenesis. For example, increased mRNA levels of oxidative stress response genes, keratinocyte growth factors, and genes in the extracellular-signal regulated mitogenactivated protein kinase (ERK1/2 MAPK) and nuclear factor kappa beta (NF-kB) pathways were observed. Curiously, we observed a minimal transcriptional response in NHEKs after exposure to multiple doses of DMA ${ }^{\prime \prime \prime}$, and these DMA ${ }^{\prime \prime \prime}$-induced transcriptional profiles were distinct from those induced by $\mathrm{i} A \mathrm{~s}^{\mathrm{III}}$ or MMA ${ }^{\prime \prime \prime}$. These results suggested that, unlike $i \mathrm{As}^{\text {III }}$ and $M A^{\prime \prime \prime}$, DMA ${ }^{\text {III }}$ is not a potent transcriptional inducer of genes that elicit carcinogenic responses in the skin, at least after short-term exposure.

Here we set out to examine the transcriptional responses of human urothelial cells (UROtsas), another major target cell type of As carcinogenesis, to determine if short-term exposure to iAs ${ }^{\prime \prime \prime}, M^{\prime \prime} A^{\prime \prime \prime}$ and DMA $^{\text {III }}$ is associated with modulation of genes implicated in UB cancer development. We found that both $\mathrm{MMA}^{\mathrm{III}}$ and $\mathrm{DMA}^{\mathrm{III}}$ perturbed molecular networks involving signaling pathways and genes implicated in UB cancer development, namely the ERK1/2 MAPK and NF-KB pathways. Together, these results suggest that even after short-term exposure to trivalent arsenicals, transcriptional alterations have occurred that may provide insight into the MOA of As-induced carcinogenesis in the UB.

\section{MATERIALS AND METHODS}

\section{Arsenicals}

The arsenicals used in this study have been previously described [26]. Briefly, working solutions of sodium $m$-arsenite $\left(\mathrm{NaAsO}_{2}\right.$; herein referred to as iAs $\left.{ }^{\prime \prime \prime}\right)$, monomethylarsonous acid in the form of $\left(\mathrm{CH}_{3}\right) \mathrm{Asl}_{2}\left(\mathrm{MMA}^{\mathrm{III}}\right)$, and dimethylarsinous acid in the form of $\left(\mathrm{CH}_{3}\right)_{2} \mathrm{Asl}$ (DMA ${ }^{\text {III }}$ ) were prepared in sterile phosphate buffered saline, $\mathrm{pH} 7.4$ (PBS) immediately before use.

\section{UROtsa Growth Conditions}

UROtsas, a human urothelial cell line transformed by the large T antigen of SV40 [27], were obtained from Dr. Zuzana Drobna (Department of Nutrition, UNC Gillings School of Global Public Health, University of North Carolina at Chapel Hill). UROtsas do not exhibit anchorage-independent cell growth and do not develop tumors in immunocompromised mice if maintained at low passage numbers $[27,28]$. Routine UROtsa growth and subculturing conditions were as described by Rossi et al. [29]. UROtsas were grown in UROtsa growth medium which contained 1:1 DMEM/Ham's F12 media (GIBCO/Invitrogen, Carlsbad, CA) supplemented with $5 \%$ fetal bovine serum (FBS; Sigma-Aldrich, St. Louis, MO) [29]. Prior to arsenical treatment, the growth medium was removed, cells were washed briefly with PBS and the growth medium was replaced with 1:1 DMEM/Ham's F12 without FBS (UROtsa dosing medium). Cells were grown in a $37^{\circ} \mathrm{C}$, $5 \% \mathrm{CO}_{2}$ humid atmosphere in the absence of antibiotic and antifungal agents and matching cell line passages were used for all endpoint analyses.

\section{Arsenical Treatment for Cytotoxicity Determination and Microarray Analysis}

The UROtsas utilized in this study have been previously shown to be a suitable cell line to study the effects of individual arsenicals as they readily absorb them but have little [30] or no [24, 31, 32] capacity to further methylate them. For cytotoxicity assays, UROtsas were seeded into 96 well plates at a density of 10,000 cells $/ \mathrm{cm}^{2}$ and grown in $250 \mu \mathrm{l} /$ well of their respective growth medium as described above until they reached $\sim 70 \%$ confluence $(48 \mathrm{~h}$ ). For each well, the culture medium was then removed, the cells were briefly rinsed with PBS, and $125 \mu$ l of UROtsa dosing medium was added. An additional $125 \mu$ of UROtsa dosing medium containing PBS (vehicle-treated controls) or $125 \mu \mathrm{l}$ PBS containing appropriate concentrations of iAs ${ }^{\text {III }}, \mathrm{MMA}^{\text {III }}$ or DMA ${ }^{\text {III }}$ was added to each well to yield final arsenical concentrations of 0 , $0.01,0.03,0.3,1,3,10,30$ and $100 \mu \mathrm{M}$. Following incubation for $24 \mathrm{~h}$ at $37^{\circ} \mathrm{C}, 5 \% \mathrm{CO}_{2}$, all media were removed and replaced with fresh UROtsa dosing medium containing $0.003 \%$ neutral red dye (Sigma \#N6264). After $3 \mathrm{~h}$ incubation at $37^{\circ} \mathrm{C}, 5 \% \mathrm{CO}_{2}$, dye taken up by viable cells was extracted with a $50 \%$ 
ethanol/1\% acetic acid solution and quantified spectrophotometrically at $540 \mathrm{~nm}$. For each arsenical dose, data were averaged from 18 wells (from three independent experiments containing 6 wells each) and normalized to vehicle-treated controls.

For RNA isolation, UROtsas were seeded at a density of 3500 cells $/ \mathrm{cm}^{2}$ in $25 \mathrm{~cm}^{2}$ flasks and grown in UROtsa growth medium as described above until they were $\sim 70 \%$ confluent $(48 \mathrm{~h})$. The cells were rinsed briefly with PBS followed by exposure to $1.0 \mu \mathrm{M}$ iAs"', $M A^{\text {III }}$, DMA ${ }^{\text {III }}$ or PBS (vehicle-treated controls) in UROtsa dosing medium for $24 \mathrm{~h}$ at $37^{\circ} \mathrm{C}, 5 \% \mathrm{CO}_{2}$. For each flask, the dosing medium was removed and the cells were lysed with $3 \mathrm{ml}$ TRIzol Reagent (Invitrogen cat\# 15596-026) according to the manufacturer's instructions. Cell lysates were stored at $-70^{\circ} \mathrm{C}$ until RNA was extracted.

\section{RNA Extraction and RNA Processing}

RNA was prepared from each lysed cell sample according to the TRIzol RNA extraction protocol (Invitrogen) followed by the RNeasy Mini Kit (Qiagen, Valencia, CA). RNA concentrations were determined spectrophotometrically $\left(\mathrm{A}_{260}\right)$. RNA quality was determined spectrophotometrically $\left(\mathrm{A}_{260} / \mathrm{A}_{280}\right)$ and by using the RNA 6000 Nano Assay with the 2100 Bioanalyzer (Agilent, Palo Alto, CA). For microarray analysis, $15 \mu \mathrm{g}$ of total RNA from each sample was converted to biotinylated cRNA using the Affymetrix 3' IVT Express Kit (cat \#901228) as described by the manufacturer (Affymetrix, Santa Clara, CA). Total cRNA was then quantified using a NanoDrop ND-1000 Spectrophotometer (NanoDrop Technologies, Wilmington, DE) and evaluated for quality after fragmentation using a 2100 Bioanalyzer. The cRNA was hybridized to Affymetrix GeneChip ${ }^{\circledR}$ Human U133 Plus 2.0 arrays overnight at $45^{\circ} \mathrm{C}$ in an Affymetrix GeneChip Hybridization Oven 640. Each chip was hybridized with cRNA obtained from one biological replicate. The hybridized arrays were washed and stained using a Fluidics Station 450 and scanned using a GeneChip Scanner 3000 7G according to the manufacturer's instructions (Affymetrix). After scanning, raw data (.cel files) were obtained using Affymetrix GeneChip ${ }^{\circledR}$ Command Console software (v. 3.0).

\section{Microarray Analyses}

Three biological replicates were used for each of the arsenical treatment groups and vehicle-treated controls. Robust Multiarray Average (RMA) was used for normalization and probe-level summarization [33] using Partek Genomics Suite TM (version 6.5) software (Partek, Inc. St. Louis, MO). Differentially expressed genes (DEGs) after arsenical treatment compared to controls were identified using the following filters in Partek: 1-way ANOVA $(p<0.05)$ followed by BenjaminiHochberg FDR $(q<0.05)$ correction and $\geq 1.5$ or $\leq-1.5$ fold change in expression. Hierarchical clustering was performed on genes that were differentially expressed in at least one arsenical treatment group relative to controls.

IPA software (version 8.8, Ingenuity ${ }^{\circledR}$ Systems, www.ingenuity.com) was used to analyze for enriched biological functions and molecular interactions associated with DEGs. The Ingenuity Knowledge Base within IPA is a literature-based database of known molecular interactions and functional annotations based on known relationships between cells, cellular components, drugs and diseases. For network generation, DEGs from each group were mapped to their corresponding object within the Ingenuity Knowledge Base. These objects were then overlaid on the global network of known molecular interactions, and smaller networks of interacting molecules within the global network were algorithmically generated based on their connectivity. Statistically significant associations of DEGs with biological functions and diseases $(p<0.005)$ and canonical pathways $(p<0.05)$ were also determined using IPA. All $p$ values were calculated in IPA using a right-tailed Fisher's exact test, which calculates the probability that associated functions, pathways and network interactions were generated due to chance alone.

\section{Quantitative Reverse Transcription-PCR (qRT-PCR)}

The same total RNA preparations were used for microarray and qRT-PCR analyses. Quantitative RTPCR was performed using the LightCycler ${ }^{\circledR} 480$ RealTime PCR System (Roche Applied Science, Indianapolis, IN) using Qiagen's QuantiTect SYBR Green RT-PCR kit (cat. \#204243) and QuantiTect $\AA$ Primer Assays according to the One Step RT PCR Protocol. Each $50 \mu \mathrm{l}$ reaction contained $10 \mathrm{ng}$ total RNA from a single biological sample, and three biological replicates were used for each treatment group and vehicle-treated controls. Beta actin (ACTB) was chosen for a reference target for each treatment group due to its stable expression in microarrays across all treatment groups. Expression levels of each target gene were normalized against ACTB expression within each treatment group and fold change values of 
the normalized target gene expression in arsenical treatment groups vs. vehicle-treated controls were calculated using the $2^{-\Delta \Delta \mathrm{CT}}$ method [34]. Statistically significant changes in target expression levels between in arsenical treatment groups compared to vehicletreated controls was determined using a Student's $t$ test. The genes and QuantiTect primer assays that detect them were: $A C T B$ as a reference target (Hs_ACTB_2_SG); dehydrogenase/reductase (SDR family) member 2 (DHRS2; Hs_DHRS2_1_SG) for the iAs ${ }^{\text {III }}$ group; matrix metalloproteinase 1 (MMP1; Hs_MMP1_1_SG) and sodium channel, nonvoltagegated 1 alpha (SCNN1A; Hs_SCNN1A_1_SG) for MMA ${ }^{\text {III }}$ group and MMP1 (Hs_MMP1_- 1 SG ) and prostate transmembrane protein, androgen induced 1 (PMEPA1; Hs_PMEPA1_1_SG) for the DMA ${ }^{\text {III }}$ group.

\section{RESULTS}

\section{Transcriptional Response after Trivalent Arsenical Exposure}

Arsenical concentrations that do not induce considerable cytoxicity/apoptosis have been shown to be relevant for studying perturbations in carcinogenic signaling pathways $[14,26,35]$. We examined the cytotoxic effects of varying doses of iAs ${ }^{\text {III }}, \mathrm{MMA}^{\mathrm{III}}$ and DMA $^{\text {III }}$ in UROtsas after $24 \mathrm{~h}$ exposure (Figure 1, Supplemental Material). The IC50s for each of the arsenicals were $43 \mu \mathrm{M}, 4.1 \mu \mathrm{M}$ and $3.7 \mu \mathrm{M}$ for iAs ${ }^{\prime \prime \prime}$, $M_{M A}{ }^{\prime \prime \prime}$ and $D_{M A} A^{\prime \prime \prime}$, respectively. For the gene

A

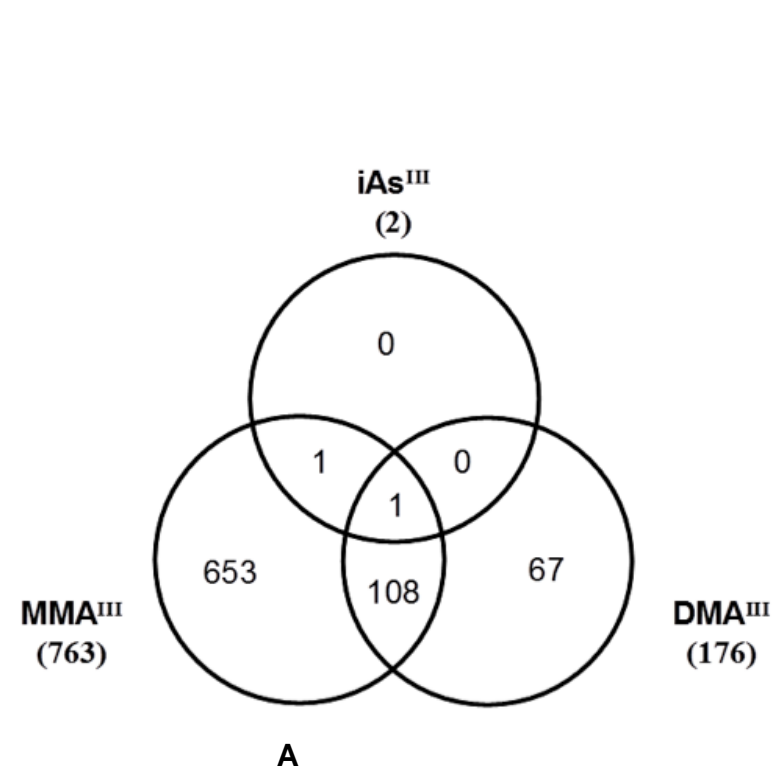

expression analyses, arsenical concentrations that resulted in $>75 \%$ UROtsa viability were selected. The 1 $\mu \mathrm{M}$ dose met this criterion for each arsenical. This dose is particularly relevant for iAs ${ }^{\text {III }}$ as long-term exposure of UROtsas at this dose results in malignant transformation [36].

Affymetrix microarrays that contained $>54,000$ probe sets representing $>38,500$ well-characterized human genes were used for the gene expression analyses. The number of unique UROtsa genes that were differentially expressed in each treatment group

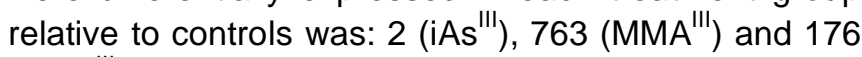
$\left(D M A^{\prime \prime \prime}\right)$ with some overlap among the genes altered by the arsenicals (Figure 1A; Table 1, Supplementary Material). Of these genes, 830 unique genes were differentially expressed in at least one treatment group (Figure 1B). A total of 108 genes were common between the $M M A^{\text {III }}$ and DMA ${ }^{\text {III }}$ groups, representing $16 \%$ and $61 \%$ of the total DEGs in these treatment groups, respectively. All of the shared DEGs between the $\mathrm{MMA}^{\text {III }}$ and DMA $\mathrm{DA}^{\mathrm{III}}$ groups had a concordant direction of modulation between the two groups.

Transcriptional trends observed in microarray experiments were verified by qRT-PCR for five selected targets for the iAs'III (DHRS2), MMA' (MMP1, SCNN1A) and DMA ${ }^{\prime \prime \prime}$ (MMP1, PMEPA1) exposure groups (Figure 2). The targets chosen collectively represent a large range of expression changes in treatment groups relative to controls. Each of the five

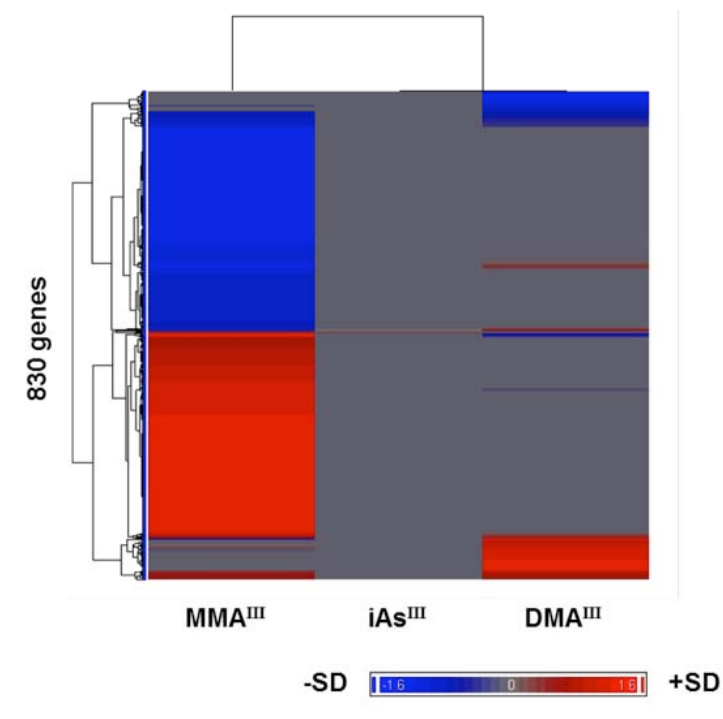

B

Figure 1: $(\mathbf{A})$. Venn diagrams displaying shared and unique UROtsa DEGs among the iAs ${ }^{\prime \prime \prime}, M_{M}{ }^{\prime \prime \prime}$ and $D M A^{\prime \prime \prime}$ treatment groups. The total number of DEGs in each treatment group is in parentheses. (B). Hierarchical clustering of the 830 unique genes in UROtsas that were differentially expressed vs. controls after $24 \mathrm{~h}$ exposure to at least one trivalent arsenical. $\mathrm{Z}$ scores of fold change values are shown. 
targets selected for qRT-PCR showed the same direction of modulation compared to controls as observed in microarray experiments. All but PMEPA1 in the DMA ${ }^{\text {III }}$ dose group had a statistically significant change in expression $(p<0.01)$ in the treatment group vs. controls as determined by qRT-PCR (Figure 2).

\section{Overview of Statistically Significant Biological Functions and Canonical Pathways Associated with DEGs}

DEGs from each of the arsenical treatment groups were analyzed for associated biological functions, diseases, and canonical pathways. The low number of DEGs in the iAs ${ }^{\text {III }}$ treatment group did not result in statistically significant results for these analyses. The five most significant biological functions/diseases associated with the DEGs for the $\mathrm{MMA}^{\mathrm{III}}$ exposure group were: cancer $\left(1.12 \times 10^{-11}\right)$, lipid metabolism $\left(2.13 \times 10^{-9}\right)$, small molecule biochemistry $\left(2.13 \times 10^{-}\right.$ $\left.{ }^{9}\right)$, vitamin and mineral metabolism $\left(2.13 \times 10^{-09}\right)$, and cell death $\left(1.76 \times 10^{-7}\right)$. For the DMA ${ }^{\text {III }}$ group, the five most significant biological functions/diseases were: cancer $\left(3.37 \times 10^{-9}\right)$, reproductive system disease $\left(3.37 \times 10^{-9}\right)$, cell-to-cell signaling and interaction (2.2 $\left.X 10^{-8}\right)$, tissue development $\left(2.2 \times 10^{-8}\right)$, and cellular development $\left(1.72 \times 10^{-7}\right)$.

The majority of the altered canonical pathways in the $\mathrm{MMA}^{\text {III }}$ and DMA ${ }^{\text {III }}$ groups are associated with one or more of the following functions: lipid metabolism, stress response/oxidative stress response, and inflammatory response (Table 2, Supplemental Material). Genes involved in stress response/oxidative stress response were generally upregulated in both the MMA ${ }^{\text {III }}$ and DMA ${ }^{\text {III }}$ groups. Oxidative stress response genes in the $M M A^{\text {III }}$ group included $N A D(P) H$ dehydrogenase, quinine 1 (NQO1), aldehyde oxididase 1 (AOX1), ferritin, heavy polypeptide 1 (FTH), and ferritin, light polypeptide ( $F T L)$, all known to play a role in the NRF2-mediated oxidative stress response pathway (Table 2A, Supplemental Material). Upregulated oxidative stress response genes in the MMA III group also included glutamate cysteine ligase, catalytic subunit $(G C L C)$, glutathione-S-transferase mu 3 (GSTM3), and glutathione reductase (GSR) in the glutathione metabolism pathway (Table 2A, Supplemental Material). The generalized stress response genes in the DMA ${ }^{\prime \prime \prime}$ group included tumor necrosis factor (TNF; aryl hydrocarbon receptor signaling pathway), heat shock $27 \mathrm{kDa}$ protein (HSP27 aka HSPB1; P38 MAPK pathway), junction mediating and regulatory protein, tumor protein 53 (TP53) cofactor (JMY; TP53 pathway) (Table 2B, Supplemental Material).

Genes that play a role in immune response were particularly enriched in the DMA ${ }^{\text {III }}$ group. These pathways contained many of the same upregulated pro-inflammatory genes such as interleukin 1, alpha (IL1A), interleukin 6 (IL6), interleukin 8 (IL8) and TNF (Table 2B, Supplemental Material).

\section{Molecular Networks Associated with DEGs}

To identify genes that encode proteins that interact in the cell and therefore may represent a coordinated response to arsenical exposure, DEGs from each group were analyzed for molecular networks. The 763 DEGs in the MMA ${ }^{\prime \prime \prime}$ group encode proteins that interact in 25 sub-networks (Table 3, Supplemental Material).

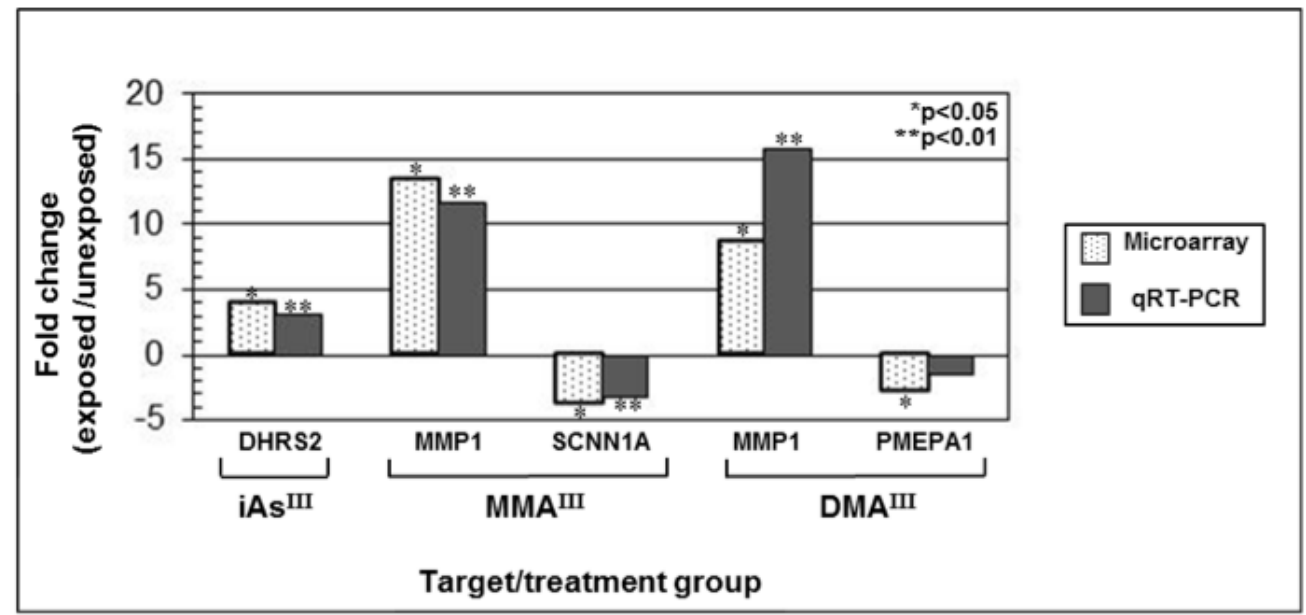

Figure 2: Comparison of gene expression changes determined by microarrays and quantitative reverse transcription-PCR (qRT-PCR) of selected genes. Statistically significant changes in gene expression compared to vehicle-treated controls are indicated as determined by microarrays $\left({ }^{*}\right)$ and $\mathrm{qRT}-\mathrm{PCR}\left({ }^{* *}\right)$. 
Eighteen out of the $25 \mathrm{MMA}^{\text {III }}$ sub-networks had overlapping proteins which generated a large, interacting protein network (interactome; $p<10^{-18}$ ) of 473 total proteins, of which 293 are encoded by MMA ${ }^{\text {III }}$ DEGs (Figure 3A). A total of 14 sub-networks were associated with 176 DMA $^{\text {III }}$ DEGs (Table 3, Supplemental Material). Four out of the $14 \mathrm{DMA}^{\text {III }}$ subnetworks were integrated and part of a larger interactome $\left(p<10^{-17}\right)$ of 137 total proteins including 59

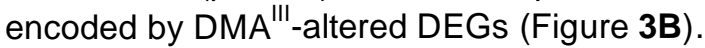

We performed a detailed analysis of the most significant molecular networks $\left(p \leq 10^{-24}\right)$ generated in the $\mathrm{MMA}^{\mathrm{III}}$ and $\mathrm{DMA}^{\mathrm{III}}$ treatment groups. Networks in both groups contained signaling proteins that play a role in pathways implicated in cancer development that

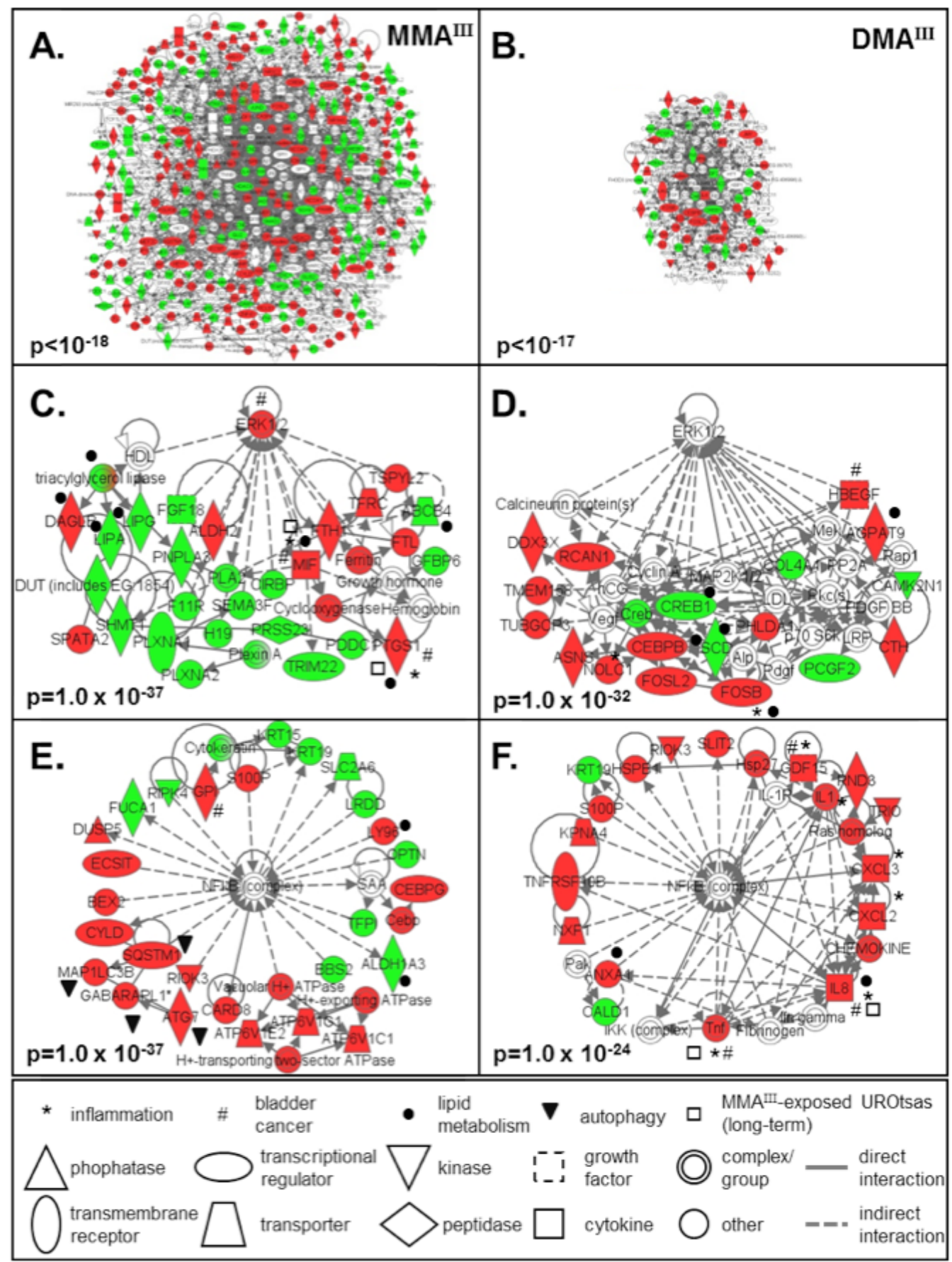

Figure 3: A-B. Large interacting molecular networks associated with the $M M A^{\prime \prime \prime}$ and DMA"I treatment groups, respectively; (C). MMA'III -induced ERK 1/2 MAPK network; (D). DMA ${ }^{\text {III }}$-induced ERK 1/2 MAPK network; (E). MMA ${ }^{\text {III }}$-induced NF-KB network; (F). DMA $A^{\text {III }}$-induced NF-KB network. Upregulated and downregulated genes are displayed in red and green, respectively and interacting genes that are not differentially expressed are not shaded. 
have been previously shown to be modulated by arsenical exposure, namely those involving ERK $1 / 2$ MAPK and the transcription factor NF-KB (Figure 3C-D and $3 \mathrm{E}-\mathrm{F}$, respectively). There were no common modulated genes among any of these ERK1/2 MAPK and NF-kB networks.

The ERK 1/2 MAPK-containing networks in the MMA ${ }^{\text {III }}$ and DMA ${ }^{\text {III }}$ groups were comprised of proteins that have associated functions related to cellular development, i.e. cellular development, cellular growth

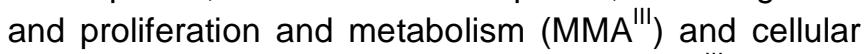

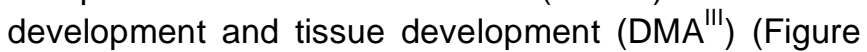
3C-D; Table 3, Supplemental Material). The NF-kBcontaining molecular networks had primary functions associated with drug/lipid metabolism, small molecule biochemistry (MMA ${ }^{\text {III) }}$ and cellular movement, hematological system function and development, and immune cell trafficking (DMA ${ }^{\text {III }}$ ) (Figure 3).

\section{Identification of UB Cancer-Associated DEGs}

We examined the DEGs in the MMA ${ }^{\text {III }}$ and DMA ${ }^{\text {III }}$ groups for genes with known associations with human cancers, particularly of the UB. In particular, we set out to identify genes that are transcriptionally altered here and have previously been shown to have altered mRNA expression or protein levels in UB cancers compared to normal UB. Several genes that are commonly overexpressed in UB cancers had increased mRNA levels in UROtsas after acute $M M A^{\prime \prime \prime}$ and/or DMA ${ }^{\prime \prime \prime}$ exposure (Table 4, Supplemental Material). These genes include growth and differentiation factor 15 (GDF15), heparin binding epidermal growth factor (HBEGF), matrix metalloproteinase 1 (MMP1), and IL8 in both the MMA ${ }^{\text {III }}$ and DMA ${ }^{\text {III }}$ groups; mitogen activated protein kinase 1 (MAPK1), heat shock $70 \mathrm{kDa}$ protein 1 (HSPA1A), heat shock $70 \mathrm{kDa}$ protein 1B (HSPA1B), macrophage migration inhibitory factor (MIF), and glucose-phosphate isomerase (GPl) in the MMA ${ }^{\text {III }}$ group; and IL1A, IL6, and tumor necrosis factor (TNF) in the DMA ${ }^{\text {III }}$ group [37-46]. Functions associated with these genes include the promotion of angiogenesis (GPI), growth (HBEGF), and tissue invasiveness (MMP1) [41, 43, 47]. In addition, many of these genes have pro-inflammatory roles, namely MIF, PTGS1, IL1A, IL6, IL8 and TNF [48-51], whereas GDF15 is immunosuppressive [52]. Several of the UB cancerassociated genes enriched amongst the ERK1/2 MAPK or NF-kB-containing molecular networks of the MMA ${ }^{\text {III }}$ (GPI, MAPK1, MIF, PTGS1) and DMA III (GDF15, HBEGF, IL8, TNF) groups (Figure 3C-F). In addition, several of the pro-inflammatory genes with known associations with UB cancers were among those that had elevated protein levels or were implicated as having important roles in UROtsa malignant transformation after prolonged $\mathrm{MMA}^{\text {III }}$ exposure, namely MAPK1, IL8, MIF, PTGS1 in the MMA ${ }^{\text {III }}$ group and IL1A, IL6, PTGS1, TNF in the DMA'II group [53-55].

\section{DISCUSSION}

In this work, we set out to investigate the transcriptional responses of UROtsas after acute exposure to iAs $s^{\prime \prime \prime}, M_{M A} A^{\prime \prime \prime}$ and DMA ${ }^{\prime \prime \prime}$. Importantly, epidemiological evidence indicates iAs is a human carcinogen with the UB as a major target organ [56]. The MOA of iAs-carcinogenesis in the UB is not well understood, but $\mathrm{MMA}^{\mathrm{III}}$ and $\mathrm{DMA} \mathrm{A}^{\mathrm{III}}$ are considered likely key carcinogenic forms. Specifically, MMA ${ }^{\text {III }}$ and DMA ${ }^{\text {III }}$ are often more cytotoxic [24], more potent enzyme inhibitors [57], cause more DNA strand breaks [58], and are more clastogenic [59] than iAs ${ }^{\text {III }}$ or pentavalent arsenicals in vitro. As further evidence of the potential for trivalent arsenicals to induce cancer, adoption of a cancer phenotype in vitro is observed much quicker in rat and human cells after chronic iAs ${ }^{\text {III }}$ exposure if they are capable of biotranforming iAs'"I to methylated metabolites [60]. In addition, a recent publication has indicated that $\mathrm{MMA}^{\text {III }}$ can act as a multi-organ transplacental carcinogen in mice [61].

In the UB, there is evidence that $\mathrm{IAs}^{\prime \prime \prime}, \mathrm{MMA}^{\prime \prime \prime}$ and $D A^{\text {III }}$ may all play an important role in cancer development. For example, in rats, DMA ${ }^{\prime \prime \prime}$ is the likely arsenical responsible for inducing carcinogenic effects in the UB upon exposure to $\mathrm{DMA}^{\mathrm{V}}$ [62-64]. In addition, UROtsas undergo malignant transformation after longterm exposure to either iAs"I or MMA ${ }^{\text {III }}[36,65]$. Together, these results suggest that $\mathrm{iAs}^{\mathrm{III}}, \mathrm{MMA}^{\mathrm{III}}$ and DMA ${ }^{\text {III }}$ have the potential to elicit carcinogenic effects in urothelial cells.

We previously determined that short-term exposure of NHEKs to trivalent arsenicals in vitro caused arsenical-specific effects in terms of the transcriptional modulation of genes implicated in the development of non-melanoma skin cancers (NMSCs) [26]. Here, we expanded this research effort to determine if genes associated with UB cancer development were modulated in UROtsas after short-term trivalent arsenical exposure. We report two key findings: (1) while the magnitude of the transcriptional responses were different between the arsenical groups, short-term exposure to both MMA ${ }^{\prime \prime \prime}$ and DMA ${ }^{\prime \prime \prime}$ resulted in modulation of ERK 1/2 MAPK- and NF-кB-associated 
signaling pathways; (2) along with other genes, these modulated signaling pathways in the $\mathrm{MMA}^{\text {III/DMA }}{ }^{\text {III }}$ groups are implicated in UB cancer development and also are implicated as important drivers of $\mathrm{MMA}^{\mathrm{III}}$ mediated UROtsa transformation.

Our data highlight differences between the transcriptional profiles for each of the arsenical treatment groups. While DMA ${ }^{\text {III }}$ was the most cytotoxic arsenical $\left(D M A^{\prime \prime \prime} \geq M M A^{\prime \prime \prime}>i A s^{\prime \prime \prime}\right)$, the greatest transcriptional response was induced by $\mathrm{MMA}^{\text {III }}$ exposure $\left(M M A^{\prime \prime \prime}>D M A^{\prime \prime \prime}>i A s^{\prime \prime \prime}\right)$ with a 4-fold greater number of genes modulated by MMA"I than DMA"I. Some similarities existed between the $\mathrm{MMA}^{\prime \prime \prime}$ and $D M A^{\prime \prime l}$ groups. All of the shared genes between these groups had a concordant direction of modulation compared to controls. Moreover, both groups were enriched for molecular networks containing signaling pathways associated with cancer development, namely the ERK1/2 MAPK and NF-KB pathways. Carcinogenic effects associated with ERK 1/2 MAPK activation include stimulating proliferation, promoting cell migration and invasion, increasing genomic instability, and preventing apoptosis [66, 67]. NF-кB can promote cancer development by stimulating proliferation, angiogenesis, and inflammation [13, 68]. NF- $\mathrm{\kappa B}$ and ERK $1 / 2$ can be activated by reactive oxygen species (ROS) and are believed to play important roles in oxidative stress-related cancers associated with metal/metalloid (e.g. As) exposure [13]. Activation of these pathways has long been associated with As exposure in a variety of cell types and is believed to play major roles in As-mediated carcinogenesis through the modulation of genes involved in proliferation, development and inflammation [14, 35, 69]. Importantly, these biological functions (cellular proliferation/development and inflammation) are among the most significant functions associated with the ERK MAPK $1 / 2$ and/or NF-KB-containing molecular networks in the $\mathrm{MMA}^{\text {III }}$ and DMA ${ }^{\text {III }}$ groups. These results indicate that short-term exposure to $1 \mu \mathrm{MMM} \mathrm{MM}^{\mathrm{III}}$ and $\mathrm{DMA}^{\mathrm{III}}$ modulate signaling pathways implicated in cancer development, including As-mediated cancers.

These data also indicate that short-term exposure to MMA ${ }^{\text {III }}$ and DMA ${ }^{\text {III }}$ perturbed signaling pathways and genes implicated in UB cancer development. Chronic inflammatory conditions and signaling pathways that converge on MAPKs, phosphatidylinositol 3-kinase (PI3K) and NF-KB are believed to play important roles in the development of many UB cancers [70-73]. For example, in UB cancer cell lines, ERK1/2 MAPK activation is associated with sustained cellular proliferation [74] and sustained ERK1/2 MAPK is associated with poor prognosis in UB cancer patients [39]. Additionally, specific inhibitors of NF-KB [75] and inhibitors that target both NF-кB and ERK1/2 MAPK [76] have been associated with the induction of apoptosis and reduced invasion/migration in human UB cell lines, respectively. Pro-inflammatory signaling is associated with the development of many UB cancers, even though UB cancer is a heterologous, multi-stage disease that likely develops via multiple pathways [77]. Most of the UB cancer-associated genes modulated in the $\mathrm{MMA}^{\text {III }}$ and/or DMA ${ }^{\text {III }}$ groups have pro-inflammatory roles and are upregulated in response to arsenical exposure relative to controls, namely IL8, PTGS1 observed for both $\mathrm{MMA}^{\mathrm{III}}$ and DMA ${ }^{\mathrm{III}}$; IL1A, IL6, TNF observed in response to DMA ${ }^{\text {III }}$ and MIF observed in response to $M M A^{\prime \prime \prime}$. These results indicate that shortterm $M_{M A} A^{\prime \prime \prime}$ and DMA $^{\text {III }}$ exposure in UROtsas modulates signaling pathways and inflammatory genes implicated as important mediators of some UB cancers.

We also observed similarities between the transcriptional profiles induced by short-term MMA ${ }^{\text {III }}$ and $\mathrm{DMA}^{\mathrm{III}}$ exposure and processes implicated in

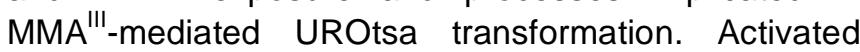
signaling pathways associated with MMA ${ }^{\text {III- }}$-mediated malignant transformation have been characterized extensively, in which chronic inflammation secondary to sustained activation of ERK 1/2 MAPK has been implicated as a potential important mechanism of carcinogenesis. In particular, the upregulation of proinflammatory cytokines/chemokines (e.g. IL1, IL6, IL8 and TNF) and signaling through pathways that involve epidermal growth factor receptor (EGFR), RAS, MAPK, PI3K, NF-KB and overexpression of certain targets of these pathways, e.g. endoperoxide synthase 1 and 2 (PTGS1/2) are believed to be important for the establishment and/or maintenance of the malignant phenotype of MMA"II'-transformed UROtsas [53-55, 78, 79]. Both iAs ${ }^{\prime \prime \prime}$ - and MMA $A^{\prime \prime \prime}$-transformed UROtsas have characteristics that are consistent with UB cancers that form under chronic inflammatory conditions. In particular, the development of SCCs (as opposed to transitional cell carcinomas, TCCs), is favored under sustained inflammatory conditions in the UB [80], and

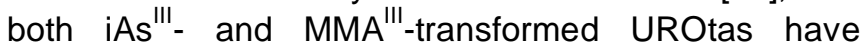
squamous characteristics and form SCCs in immunocompromised mice $[36,65]$. As previously mentioned, transcript levels of several genes implicated

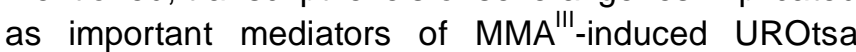
transformation were increased in this study, namely MAPK1, IL8, MIF, PTGS1 in the MMA ${ }^{\text {III }}$ group and

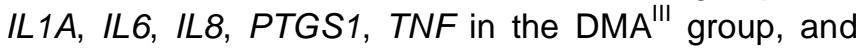


the expression/overexpression of these genes or the proteins they encode have been previously associated with UB cancers [38, 39, 42, 44-46, 81]. Taken together, these results not only indicate that proinflammatory signaling that occurs concurrently with

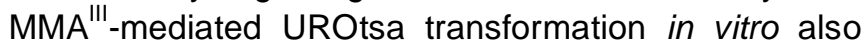
occurs in UROtsas after short-term exposure to MMA III or DMA"I', but that these modulated signaling pathways and pro-inflammatory genes are consistent with those believed to play important roles in the development of UB cancers.

Of note, we observed that both $\mathrm{MMA}^{\mathrm{III}}$ and $\mathrm{DMA} \mathrm{A}^{\mathrm{III}}$ were capable of inducing pathways and genes that are implicated in UB cancer development and MMA ${ }^{\text {III- }}$ mediated malignant transformation of UROtsas. Few studies have investigated the gene expression effects in human urothelial cells after DMA ${ }^{\text {III }}$ exposure [82] and to our knowledge, the capacity of DMA ${ }^{\text {III }}$ to induce urothelial cell transformation in vitro is unknown. In our previous study, genes implicated in NMSC development, including those that signal through ERK1/2 MAPK and NF-KB, were strongly associated with MMA $^{\text {III }}$ exposure but not associated with DMA ${ }^{\text {II }}$ exposure [26]. MMA ${ }^{\text {III }}$ is often viewed as a particularly likely carcinogenic metabolite of iAs as it is often the most cytotoxic arsenical observed in vitro [24] and has recently been shown to be a multi-organ transplacental carcinogen [61]. Also, As-exposed populations with increased urinary $\mathrm{MMA}^{\mathrm{III+V}} / \mathrm{DMA}^{\mathrm{III+}}$ ratios have been associated with increased susceptibility to Asassociated cancers, including NMSCs and UB cancers [83-85]. It has been clearly established that DMA ${ }^{\text {III }}$ can induce carcinogenic effects such as the production of ROS and DNA strand breaks and is the likely reactive metabolite contributing to UB cancers in $\mathrm{DMA}^{\mathrm{V}}$ exposed rats [86-88]. Here, we demonstrate that unlike the DMA ${ }^{\prime \prime \prime}$-induced transcriptional response observed in NHEKs, DMA III exposure is associated with carcinogenic transcriptional alterations in human urothelial cells, suggesting cell-specific responses to DMA ${ }^{\text {III }}$ may exist. Individuals have different capacities to biotransform iAs to MMAs and DMAs, resulting in varying proportions of MMAs and DMAs in urine and tissues [21, 89]. Therefore, taken together, these results suggest cell-specific responses to arsenicals and interindividual differences in iAs metabolism likely play important roles in the susceptibility to Asassociated disease.

In summary, this study reveals that acute MMA ${ }^{\text {III }}$ and DMA ${ }^{\text {III }}$ exposures in UROtsas result in transcriptional alterations of pathways implicated in the development of UB cancers and MMA ${ }^{\text {III-}}$-mediated
UROtsa transformation in vitro. Future studies should help inform which arsenical(s) exert carcinogenic effects in the UB and inform the relationship of molecular events that drive UB cancers of different etiologies.

\section{ACKNOWLEDGEMENTS}

This work was supported in part by NIEHS T32 ES7018 and ES019315. The authors would like to thank Dr. Kirk Kitchin and Dr. Amy Wang for reviewing this manuscript. This manuscript was reviewed and approved for publication by the National Health and Environmental Effects Research Laboratory of the U.S. Environmental Protection Agency (EPA). Approval does not signify that the contents of this article necessarily reflect the views or policies of the EPA. Mention of trade names or commercial products does not constitute endorsement or recommendations for use.

\section{ABBREVIATIONS}

$$
\begin{array}{ll}
\text { As } & =\text { arsenic } \\
D^{\prime \prime I I} & =\text { dimethylarsinous acid } \\
\text { DMA }^{\mathrm{V}} & =\text { dimethylarsinic acid } \\
\text { DEGs } & =\text { differentially expressed genes }
\end{array}
$$

ERK1/2 MAPK = extracellular signal- regulated kinase $1 / 2$ mitogen-activated protein kinase

iAs" = arsenite

$\mathrm{iAs}^{\mathrm{V}} \quad=$ arsenate

IC50 = half maximal inhibitory concentration

MMA $A^{\prime \prime \prime} \quad=$ monomethylarsonous acid

$\mathrm{MMA}^{\mathrm{V}} \quad=$ monomethylarsonic acid

MOA $=$ mode of action

NF- $\mathrm{KB} \quad=$ nuclear factor kappa beta

NRF2 $=$ nuclear factor-E2-related factor 2

qRT-PCR = quantitative reverse transcription polymerase chain reaction

UB = urinary bladder

\section{SUPPLEMENTAL MATERIALS}

The supplemental figure and tables can be downloaded from the journal website along with the article. 


\section{REFERENCES}

[1] Kapaj S, Peterson H, Liber K, Bhattacharya P. Human health effects from chronic arsenic poisoning--a review. J Environ Sci Health A Tox Hazard Subst Environ Eng 2006; 41: 2399428.

[2] National Research Council. Arsenic in the Drinking Water. Washington, D.C.: National Academy Press 1999.

[3] Nordstrom DK. Public health. Worldwide occurrences of arsenic in ground water. Science 2002; 296: 2143-5. http://dx.doi.org/10.1126/science.1072375

[4] Oremland RS, Stolz JF. The ecology of arsenic. Science 2003; 300: 939-44.

http://dx.doi.org/10.1126/science.1081903

[5] Centeno JA, Tseng $\mathrm{CH}$, Van der Voet GB, Finkelman RB. Global impacts of geogenic arsenic: a medical geology research case. Ambio 2007; 36: 78-81. http://dx.doi.org/10.1579/00447447(2007)36[78:GIOGAA]2.0.CO;2

[6] World Health Organization. Guidelines for drinking water quality. Geneva: WHO Press; 2006.

[7] Tapio S, Grosche B. Arsenic in the aetiology of cancer. Mutat Res 2006; 612: 215-46. http://dx.doi.org/10.1016/j.mrrev.2006.02.001

[8] Some Drinking-water Disinfectants and Contaminants, including Arsenic. In: IARC Monographs on the evaluation of carcinogenic risks to humans. Lyon, France: IARC Scientific Publications 2004.

[9] Rossman TG. Mechanism of arsenic carcinogenesis: an integrated approach. Mutat Res 2003; 533: 37-65. http://dx.doi.org/10.1016/i.mrfmmm.2003.07.009

[10] Schuhmacher-Wolz U, Dieter HH, Klein D, Schneider K. Oral exposure to inorganic arsenic: evaluation of its carcinogenic and non-carcinogenic effects. Crit Rev Toxicol 2009; 39: 27198.

http://dx.doi.org/10.1080/10408440802291505

[11] Kitchin KT, Conolly R. Arsenic-induced carcinogenesis-oxidative stress as a possible mode of action and future research needs for more biologically based risk assessment. Chem Res Toxicol 2010; 23: 327-35. http://dx.doi.org/10.1021/tx900343d

[12] Leonard SS, Harris GK, Shi X. Metal-induced oxidative stress and signal transduction. Free Radic Biol Med 2004; 37: 1921-42.

http://dx.doi.org/10.1016/j.freeradbiomed.2004.09.010

[13] Valko M, Rhodes CJ, Moncol J, Izakovic M, Mazur M. Free radicals, metals and antioxidants in oxidative stress-induced cancer. Chem Biol Interact 2006; 160: 1-40. http://dx.doi.org/10.1016/..cbi.2005.12.009

[14] Gentry PR, McDonald TB, Sullivan DE, Shipp AM, Yager JW, Clewell HJ, 3rd. Analysis of genomic dose-response information on arsenic to inform key events in a mode of action for carcinogenicity. Environ Mol Mutagen 2010; 51: 114.

[15] Gradecka D, Palus J, Wasowicz W. Selected mechanisms of genotoxic effects of inorganic arsenic compounds. Int J Occup Med Environ Health 2001; 14: 317-28.

[16] Kligerman AD, Tennant $A H$. Insights into the carcinogenic mode of action of arsenic. Toxicol Appl Pharmacol 2007; 222: 281-8.

http://dx.doi.org/10.1016/.taap.2006.10.006

[17] Kitchin KT, Wallace K. The role of protein binding of trivalent arsenicals in arsenic carcinogenesis and toxicity. J Inorg Biochem 2008; 102: 532-9. http://dx.doi.org/10.1016/i.jinorgbio.2007.10.021

[18] Ren X, McHale CM, Skibola CF, Smith AH, Smith MT, Zhang $\mathrm{L}$. An emerging role for epigenetic dysregulation in arsenic toxicity and carcinogenesis. Environ Health Perspect 2011; 119: 11-9.

http://dx.doi.org/10.1289/ehp.1002114

[19] Thomas DJ, Styblo M, Lin S. The cellular metabolism and systemic toxicity of arsenic. Toxicol Appl Pharmacol 2001; 176: $127-44$.

http://dx.doi.org/10.1006/taap.2001.9258

[20] Mandal BK, Ogra Y, Anzai K, Suzuki KT. Speciation of arsenic in biological samples. Toxicol Appl Pharmacol 2004; 198: 307-18.

http://dx.doi.org/10.1016/j.taap.2003.10.030

[21] Vahter M. Methylation of inorganic arsenic in different mammalian species and population groups. Sci Prog 1999; 82 ( Pt 1): 69-88.

[22] Valenzuela OL, Borja-Aburto VH, Garcia-Vargas GG, CruzGonzalez MB, Garcia-Montalvo EA, Calderon-Aranda ES, et al. Urinary trivalent methylated arsenic species in a population chronically exposed to inorganic arsenic. Environ Health Perspect 2005; 113: 250-4.

http://dx.doi.org/10.1289/ehp.7519

[23] Cohen SM, Arnold LL, Eldan M, Lewis AS, Beck BD. Methylated arsenicals: the implications of metabolism and carcinogenicity studies in rodents to human risk assessment. Crit Rev Toxicol 2006; 36: 99-133. http://dx.doi.org/10.1080/10408440500534230

[24] Styblo M, Del Razo LM, Vega L, et al. Comparative toxicity of trivalent and pentavalent inorganic and methylated arsenicals in rat and human cells. Arch Toxicol 2000; 74: 289-99. http://dx.doi.org/10.1007/s002040000134

[25] Kitchin KT, Ahmad S. Oxidative stress as a possible mode of action for arsenic carcinogenesis. Toxicol Lett 2003; 137: 313. http://dx.doi.org/10.1016/S0378-4274(02)00376-4

[26] Bailey KA, Hester SD, Knapp GW, Owen RD, Thai SF. Gene expression of normal human epidermal keratinocytes modulated by trivalent arsenicals. Mol Carcinog 2010; 49: 981-98.

http://dx.doi.org/10.1002/mc.20677

[27] Petzoldt JL, Leigh IM, Duffy PG, Sexton C, Masters JR. Immortalisation of human urothelial cells. Urol Res 1995; 23 : 377-80. http://dx.doi.org/10.1007/BF00698738

[28] Kawamata H, Kameyama S, Nan L, Kawai K, Oyasu R. Effect of epidermal growth factor and transforming growth factor beta 1 on growth and invasive potentials of newly established rat bladder carcinoma cell lines. Int $\mathrm{J}$ Cancer 1993; 55: 968-73.

http://dx.doi.org/10.1002/ijc.2910550616

[29] Rossi MR, Masters JR, Park S, Todd JH, Garrett SH, Sens MA, et al. The immortalized UROtsa cell line as a potential cell culture model of human urothelium. Environ Health Perspect 2001; 109: 801-8.

http://dx.doi.org/10.1289/ehp.01109801

[30] Bredfeldt TG, Kopplin MJ, Gandolfi AJ. Effects of arsenite on UROtsa cells: low-level arsenite causes accumulation of ubiquitinated proteins that is enhanced by reduction in cellular glutathione levels. Toxicol Appl Pharmacol 2004; 198: 412-8. http://dx.doi.org/10.1016/j.taap.2003.10.013

[31] Lin S, Shi Q, Nix FB, et al. A novel S-adenosyl-Lmethionine:arsenic(III) methyltransferase from rat liver cytosol. J Biol Chem 2002; 277: 10795-803. http://dx.doi.org/10.1074/jbc.M110246200

[32] Drobna Z, Waters SB, Devesa V, Harmon AW, Thomas DJ, Styblo M. Metabolism and toxicity of arsenic in human urothelial cells expressing rat arsenic ( +3 oxidation state)methyltransferase. Toxicol Appl Pharmacol 2005; 207: 14759.

http://dx.doi.org/10.1016/j.taap.2004.12.007 
[33] Irizarry RA, Hobbs B, Collin F, Beazer-Barclay YD, Antonellis $\mathrm{KJ}$, Scherf $\mathrm{U}$, et al. Exploration, normalization, and summaries of high density oligonucleotide array probe level data. Biostatistics 2003; 4: 249-64.

http://dx.doi.org/10.1093/biostatistics/4.2.249

[34] Livak KJ, Schmittgen TD. Analysis of relative gene expression data using real-time quantitative PCR and the 2(Delta Delta C(T)) Method. Methods 2001; 25: 402-8.

[35] Dong Z. The molecular mechanisms of arsenic-induced cell transformation and apoptosis. Environ Health Perspect 2002; 110(Suppl 5): 757-9.

http://dx.doi.org/10.1289/ehp.02110s5757

[36] Sens DA, Park S, Gurel V, Sens MA, Garrett SH, Somji S. Inorganic cadmium- and arsenite-induced malignant transformation of human bladder urothelial cells. Toxicol Sci 2004; 79: 56-63.

http://dx.doi.org/10.1093/toxsci/kfh086

[37] Costa VL, Henrique R, Danielsen SA, et al. Three epigenetic biomarkers, GDF15, TMEFF2, and VIM, accurately predict bladder cancer from DNA-based analyses of urine samples. Clin Cancer Res 2010; 16: 5842-51.

http://dx.doi.org/10.1158/1078-0432.CCR-10-1312

[38] Margel D, Pesvner-Fischer M, Baniel J, Yossepowitch O, Cohen IR. Stress Proteins and Cytokines are Urinary Biomarkers for Diagnosis and Staging of Bladder Cancer. Eur Urol 2011; 59: 113-9.

http://dx.doi.org/10.1016/j.eururo.2010.10.008

[39] Karlou M, Saetta AA, Korkolopoulou P, et al. Activation of extracellular regulated kinases (ERK1/2) predicts poor prognosis in urothelial bladder carcinoma and is not associated with B-Raf gene mutations. Pathology 2009; 41: 327-34.

http://dx.doi.org/10.1080/00313020902885011

[40] Nutt JE, Mellon JK, Qureshi K, Lunec J. Matrix metalloproteinase-1 is induced by epidermal growth factor in human bladder tumour cell lines and is detectable in urine of patients with bladder tumours. Br J Cancer 1998; 78: 215-20. http://dx.doi.org/10.1038/bjc.1998.467

[41] Amsellem-Ouazana D, Bieche I, Tozlu S, Botto H, Debre B, Lidereau R. Gene expression profiling of ERBB receptors and ligands in human transitional cell carcinoma of the bladder. J Urol 2006; 175: 1127-32.

\section{http://dx.doi.org/10.1016/S0022-5347(05)00317-4}

[42] Guo YS, Dai YP, Li W, Liu LD. [Expression and significance of macrophage migration inhibitory factor in bladder urothelial cell carcinoma]. Zhonghua Zhong Liu Za Zhi 2011; 33: 28-31.

[43] Jung I, Messing E. Molecular mechanisms and pathways in bladder cancer development and progression. Cancer Control 2000; 7: 325-34.

[44] Seddighzadeh $M$, Larsson $P$, Ulfgren AC, et al. Low IL1alpha expression in bladder cancer tissue and survival. Eur Urol 2003; 43: 362-8.

http://dx.doi.org/10.1016/S0302-2838(03)00047-2

[45] Cardillo MR, Sale P, Di Silverio F. Heat shock protein-90, IL6 and IL-10 in bladder cancer. Anticancer Res 2000; 20: 4579-83.

[46] Feng CC, Wang PH, Ding Q, et al. Expression of pigment epithelium-derived factor and tumor necrosis factor-alpha is correlated in bladder tumor and is related to tumor angiogenesis. Urol Oncol 2011;

http://dx.doi.org/10.1016/j.urolonc.2010.12.001

[47] Hojilla CV, Mohammed FF, Khokha R. Matrix metalloproteinases and their tissue inhibitors direct cell fate during cancer development. Br J Cancer 2003; 89: 1817-21. http://dx.doi.org/10.1038/sj.bjc.6601327

[48] Conroy H, Mawhinney L, Donnelly SC. Inflammation and cancer: macrophage migration inhibitory factor (MIF)--the potential missing link. QJM 2010; 103: 831-6. http://dx.doi.org/10.1093/qjmed/hcq148
[49] Perrone MG, Scilimati A, Simone L, Vitale P. Selective COX1 inhibition: A therapeutic target to be reconsidered. Curr Med Chem 2010; 17: 3769-805. http://dx.doi.org/10.2174/092986710793205408

[50] Balkwill F, Mantovani A. Inflammation and cancer: back to Virchow? Lancet 2001; 357: 539-45. http://dx.doi.org/10.1016/S0140-6736(00)04046-0

[51] Ariztia EV, Lee CJ, Gogoi R, Fishman DA. The tumor microenvironment: key to early detection. Crit Rev Clin Lab Sci 2006; 43: 393-425.

http://dx.doi.org/10.1080/10408360600778836

[52] Vanhara P, Hampl A, Kozubik A, Soucek K. Growth/differentiation factor-15: prostate cancer suppressor or promoter? Prostate Cancer Prostatic Dis 2012;

[53] Escudero-Lourdes C, Medeiros MK, Cardenas-Gonzalez MC, Wnek SM, Gandolfi JA. Low level exposure to monomethyl arsonous acid-induced the over-production of inflammationrelated cytokines and the activation of cell signals associated with tumor progression in a urothelial cell model. Toxicol Appl Pharmacol 2010; 244: 162-73. http://dx.doi.org/10.1016/j.taap.2009.12.029

[54] Eblin KE, Bredfeldt TG, Buffington S, Gandolfi AJ. Mitogenic signal transduction caused by monomethylarsonous acid in human bladder cells: role in arsenic-induced carcinogenesis. Toxicol Sci 2007; 95: 321-30. http://dx.doi.org/10.1093/toxsci/kfl160

[55] Escudero-Lourdes C, Wu T, Camarillo JM, Gandolfi AJ. Interleukin-8 (IL-8) over-production and autocrine cell activation are key factors in monomethylarsonous acid [MMA(III)]-induced malignant transformation of urothelial cells. Toxicol Appl Pharmacol 2012; 258: 10-8. http://dx.doi.org/10.1016/j.taap.2011.10.002

[56] Guha Mazumder DN. Chronic arsenic toxicity \& human health. Indian J Med Res 2008; 128: 436-47.

[57] Styblo M, Serves SV, Cullen WR, Thomas DJ. Comparative inhibition of yeast glutathione reductase by arsenicals and arsenothiols. Chem Res Toxicol 1997; 10: 27-33. http://dx.doi.org/10.1021/tx960139g

[58] Mass MJ, Tennant A, Roop BC, et al. Methylated trivalent arsenic species are genotoxic. Chem Res Toxicol 2001; 14: 355-61.

\section{http://dx.doi.org/10.1021/tx0002511}

[59] Kligerman AD, Doerr CL, Tennant $A H$, et al. Methylated trivalent arsenicals as candidate ultimate genotoxic forms of arsenic: induction of chromosomal mutations but not gene mutations. Environ Mol Mutagen 2003; 42: 192-205. http://dx.doi.org/10.1002/em.10192

[60] Kojima C, Ramirez DC, Tokar EJ, et al. Requirement of arsenic biomethylation for oxidative DNA damage. J Natl Cancer Inst 2009; 101: 1670-81.

http://dx.doi.org/10.1093/jnci/djp414

[61] Tokar EJ, Diwan BA, Thomas DJ, Waalkes MP. Tumors and proliferative lesions in adult offspring after maternal exposure to methylarsonous acid during gestation in CD1 mice. Arch Toxicol 2012; 86: 975-82.

[62] Wei M, Wanibuchi $\mathrm{H}$, Morimura $\mathrm{K}$, et al. Carcinogenicity of dimethylarsinic acid in male F344 rats and genetic alterations in induced urinary bladder tumors. Carcinogenesis 2002; 23: 1387-97.

http://dx.doi.org/10.1093/carcin/23.8.1387

[63] Wei M, Wanibuchi H, Yamamoto S, Li W, Fukushima S. Urinary bladder carcinogenicity of dimethylarsinic acid in male F344 rats. Carcinogenesis 1999; 20: 1873-6. http://dx.doi.org/10.1093/carcin/20.9.1873

[64] Cohen SM, Arnold LL, Uzvolgyi E, et al. Possible role of dimethylarsinous acid in dimethylarsinic acid-induced urothelial toxicity and regeneration in the rat. Chem Res Toxicol 2002; 15: 1150-7. http://dx.doi.org/10.1021/tx020026z 
[65] Bredfeldt TG, Jagadish B, Eblin KE, Mash EA, Gandolfi AJ. Monomethylarsonous acid induces transformation of human bladder cells. Toxicol Appl Pharmacol 2006; 216: 69-79. http://dx.doi.org/10.1016/j.taap.2006.04.011

[66] Kim EK, Choi EJ. Pathological roles of MAPK signaling pathways in human diseases. Biochim Biophys Acta 2010; 1802: 396-405.

[67] Bodart JF. Extracellular-regulated kinase-mitogen-activated protein kinase cascade: unsolved issues. J Cell Biochem 2010; 109: 850-7.

[68] Morgan MJ, Liu ZG. Crosstalk of reactive oxygen species and NF-kappaB signaling. Cell Res 2011; 21: 103-15. http://dx.doi.org/10.1038/cr.2010.178

[69] Yang C, Frenkel K. Arsenic-mediated cellular signal transduction, transcription factor activation, and aberrant gene expression: implications in carcinogenesis. J Environ Pathol Toxicol Oncol 2002; 21: 331-42.

[70] Dangle PP, Zaharieva B, Jia H, Pohar KS. Ras-MAPK pathway as a therapeutic target in cancer--emphasis on bladder cancer. Recent Pat Anticancer Drug Discov 2009; 4: 125-36. http://dx.doi.org/10.2174/157489209788452812

[71] Knowles MA, Platt FM, Ross RL, Hurst CD. Phosphatidylinositol 3-kinase (PI3K) pathway activation in bladder cancer. Cancer Metastasis Rev 2009; 28: 305-16. http://dx.doi.org/10.1007/s10555-009-9198-3

[72] Karashima $T$, Sweeney $P$, Kamat $A$, et al. Nuclear factorkappaB mediates angiogenesis and metastasis of human bladder cancer through the regulation of interleukin-8. Clinical Cancer Research: an Official Journal of the American Association for Cancer Research 2003; 9: 2786-97.

[73] Schulz WA. Understanding urothelial carcinoma through cancer pathways. Int J Cancer 2006; 119: 1513-8. http://dx.doi.org/10.1002/ijc.21852

[74] Kumar B, Sinclair J, Khandrika L, Koul S, Wilson S, Koul HK. Differential effects of MAPKs signaling on the growth of invasive bladder cancer cells. Int J Oncol 2009; 34: 1557-64.

[75] Horiguchi Y, Kuroda K, Nakashima J, Murai M, Umezawa K. Antitumor effect of a novel nuclear factor-kappa B activation inhibitor in bladder cancer cells. Expert Rev Anticancer Ther 2003; 3: 793-8.

http://dx.doi.org/10.1586/14737140.3.6.793

[76] Zhang L, Chen W, Li X. A novel anticancer effect of butein: inhibition of invasion through the ERK1/2 and NF-kappa B signaling pathways in bladder cancer cells. FEBS Lett 2008; 582: $1821-8$

http://dx.doi.org/10.1016/j.febslet.2008.04.046

[77] Cordon-Cardo C. Molecular alterations associated with bladder cancer initiation and progression. Scand J Urol Nephrol Suppl 2008; 154-65. http://dx.doi.org/10.1080/03008880802291915

[78] Eblin KE, Jensen TJ, Wnek SM, Buffington SE, Futscher BW, Gandolfi AJ. Reactive oxygen species regulate properties of transformation in UROtsa cells exposed to monomethylarsonous acid by modulating MAPK signaling. Toxicology 2009; 255: 107-14.

http://dx.doi.org/10.1016/j.tox.2008.10.007

[79] Wnek SM, Jensen TJ, Severson PL, Futscher BW, Gandolfi AJ. Monomethylarsonous acid produces irreversible events resulting in malignant transformation of a human bladder cell line following 12 weeks of low-level exposure. Toxicological Sciences: An Official Journal of the Society of Toxicology 2010; 116: 44-57.

[80] Cohen SM. Urinary bladder carcinogenesis. Toxicol Pathol 1998; 26: 121-7. http://dx.doi.org/10.1177/019262339802600114

[81] Bostrom PJ, Aaltonen V, Soderstrom KO, Uotila P, Laato M. Expression of cyclooxygenase- 1 and -2 in urinary bladder carcinomas in vivo and in vitro and prostaglandin E2 synthesis in cultured bladder cancer cells. Pathology 2001; 33: 469-74. http://dx.doi.org/10.1080/00313020120083188

[82] Su PF, Hu YJ, Ho IC, Cheng YM, Lee TC. Distinct gene expression profiles in immortalized human urothelial cells exposed to inorganic arsenite and its methylated trivalent metabolites. Environ Health Perspect 2006; 114: 394-403. http://dx.doi.org/10.1289/ehp.8174

[83] Huang YK, Huang YL, Hsueh YM, et al. Arsenic exposure, urinary arsenic speciation, and the incidence of urothelial carcinoma: a twelve-year follow-up study. Cancer Causes Control 2008; 19: 829-39. http://dx.doi.org/10.1007/s10552-008-9146-5

[84] Steinmaus C, Bates MN, Yuan Y, et al. Arsenic methylation and bladder cancer risk in case-control studies in Argentina and the United States. J Occup Environ Med 2006; 48: 47888.

http://dx.doi.org/10.1097/01.jom.0000200982.28276.70

[85] Chen YC, Guo YL, Su HJ, et al. Arsenic methylation and skin cancer risk in southwestern Taiwan. J Occup Environ Med 2003; 45: 241-8.

http://dx.doi.org/10.1097/01.jom.0000058336.05741.e8

[86] Cohen SM, Ohnishi T, Arnold LL, Le XC. Arsenic-induced bladder cancer in an animal model. Toxicol Appl Pharmacol 2007; 222: 258-63.

http://dx.doi.org/10.1016/j.taap.2006.10.010

[87] Nesnow S, Roop BC, Lambert G, et al. DNA damage induced by methylated trivalent arsenicals is mediated by reactive oxygen species. Chem Res Toxicol 2002; 15: 162734. http://dx.doi.org/10.1021/tx025598y

[88] Soto-Reyes E, Del Razo LM, Valverde M, Rojas E. Role of the alkali labile sites, reactive oxygen species and antioxidants in DNA damage induced by methylated trivalent metabolites of inorganic arsenic. Biometals 2005; 18: 493506.

http://dx.doi.org/10.1007/s10534-005-0858-7

[89] Hughes MF. Biomarkers of exposure: a case study with inorganic arsenic. Environ Health Perspect 2006; 114: 17906.

\section{DOI: http://dx.doi.org/10.6000/1929-2279.2012.01.01.10}

(C) 2012 Bailey et al.; Licensee Lifescience Global.

This is an open access article licensed under the terms of the Creative Commons Attribution Non-Commercial License (http://creativecommons.org/licenses/by-nc/3.0/) which permits unrestricted, non-commercial use, distribution and reproduction in any medium, provided the work is properly cited. 